検を終った。

カップリング 4000 馬力の蒸気タービンにより， てまかい菌型のカップリング执よび正逆転流体継手に ついても研究している，翼振動 翼をとめノズルを回 して振動を計っている。グランド 最も損傷の少ない うのを求めている。

[今井兼一郎]

\section{$621.438: 623.85(42)$}

[325]药国海軍艦艇用がスタービン［G.Waller， The Oil Engine and Gas Turbine, 1953-4, p. 454 $\sim 456$, 図 4] 海軍大将 Denny 郷が Pyestock $の$ 新設海軍ガスタービン試験場を訪間したさいにのべた ところによると，英海軍では将来あらゆる級の艦艇に ガスダービンを用いることを決意している，小艦艇で は主機械として, 空母巡洋艦駆逐艦零は 4/5 上上の全 う時に用いるとととし，発電機用としては近くに用い るようになる。主力艦全力の1/5というと8000〜
$25000 \mathrm{BIP}$ ，小艦艇用としては $1000 \sim 12000 \mathrm{BH}$ ，発 電ないしは消火用としては 30〜1500 BP ということ になる。．小形重量当り出力大なるとと，保持の容易等 が海軍として趓力のあるとてろで永い目では蒸気タ一 ビン，ディーゼルに扣き代るものと考えている。重油 を戻の海積なしに然焼できるか，または冷却されたタ 一ビンによって蒸留油者用いてきわめて高效率苍うる かいずれによってての夢加笑現できると洘えている。 このために添加片を研究し，また冷却潜定研究してい る．更に英国に扣ける船用劦スタービンの発迲につい て簢単にのべて, 構造について初期の蒸気タービン近 いもの方大き〈変化し “Auris”号の $860 \mathrm{~kW}$ と Ruston の TA 型 $750 \mathrm{~kW}$ と比較すると共に 100000 時間の寿命に対して同じ熱效率で前者は 50 t，後者は $15 \mathrm{t}$ と軽〉なっていることは注目に值するといってい る。

[今井兼一郎]

\title{
14. 圧縮機および送風機
}

\section{$621.515: 621.438 .031 .3$}

[326]、小ガスタービン压縮機用の遗心迸風機 [IVan E. Speer, A.S.M.E., Trans., 1953-4, Vol. 75,No. 3 , p. 395 407, 図 18] 航空エンジンの大出为化 にともない二ュマテックスダータが注目され，その压 縮空気源としてガスダービン医㴼機の製作に力がそそ がれた。この論交はその試作にあたった Ai Research Manufacturing Co. でのガスダービン压亂機（Model GTC 85）の逗心送風㙨の試作経過報告である。その
出力を压㜚塋気として出すため送風機の流量範囲が広 くなり，その範囲でできる限り効率を高く一定にした い. この送風機では圧力比 $3 \cdot 36$, 流量 $11^{\prime} \mathrm{kg} / \mathrm{s}$, 効 率 $\geq 80 \%$ ，空気を取り出さない時の流量は最大流量の 327 である.この要求を满すべく 30 度後间羽根で 2 段にしたが，設棓け祭して基礎をなした考え，参考に した交城，その砸究経過が述べられてれらに関して寄 せられた詃論がある。

[岡踰 卓郎]

\section{6. 機構・自動制御および機栈要素}

\section{$621-52$}

〔327〕サンプリング自動制御を振幅变拥と見を一つ の解䉼 [William K. Linvill, A.I.E.E., Trans., 1951, Vol. 70，p. 1779〜 1788，図 14] レーダの追彷制御 やディジタルコンピェダを使った自動制御で行われる 周其甠的検出機構を，㭘出周期 $T$ ごとに出る強さ・Iのパ ルスを搬送波として大力信号（検法すべき制御量ある わ(溜差) を変調するモジュレータと考え，てれにつ いてラプラス変換を用いた笑用的な解析洗が示されて いる。乙れ亿よれば，線型制御理諭で既知の知識（认 クトル敦踇やナイキストの安定判別など）を志用して， このような不連続制御系の综定判別や制御特性が比較 的容易に解䏣される。主な結果をあげれば，かかる自 動制御系ではその中をめぐる信号の祘波数が必ず $2 \pi$ $T の$ 榊期をむつで，真の信号ををの险の信号（真の

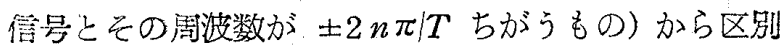
できなければ適正な訂正動作は望めない，したがって 目標值はその周波数が $0 \sim \pi / T$ の範囲を越えてはなら ないし，ての糸作用する外乱ものっくりしているこ と方哭まれる。もしも外乱が $\pi / T$ 以上の周波数成分 在含んでいれば，それは制御ループをひとめぐりする うちに十分に減衰することが必要である。討諭に拀い て Raggazini がこの方法といわ们るパルス伝墶かん

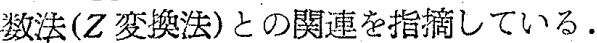

[伊沢棓介]
[J. Boyd and A. A. Raimondi, Mech. Engg., Vol. 75, No. 5, 1953, p. 380 386, 困 17〕. ピボット 式パットジャーナル軸受は軸の偏心を小さくできる等 種々の理由で高速スピンドルの軸受等に用いられてい る。この論文はピボットジャーナル軸受の摩虔特性を

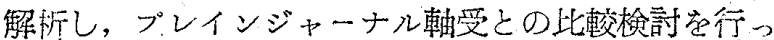
たものである。初めにピボット式パット軸受について 一つのパット中心荷重作用線が通るようにパットが 金周に配列された場合と, 荷重作用線がパット間を通 るように配列された場合とについて解析を行ってい る。後者の方が前者よりも荷重分在がー様となり，筫

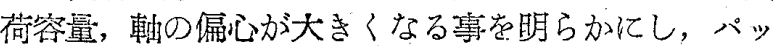
トの数による影得も調べている。次にピボット式パッ ト韩受とプレインジャーナル朝受と比敷して扣り，同 一の直径一湢比の軸受について最小淊膜厚さ经後者の 方为大きく，軸の偏心率の大小值径䒇比によって

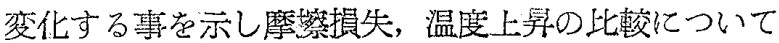
も言改している。同軸受の解析結果分ら次のように結 論している。ピボット式パットジャーナル䣐受はプレ インジャーナル軸受に比較して特にすぐれだ特性は見 られない。ただ有益な点としては一般のプレイシジャ ーナル軸受に用いられるすき間よりも小さいすき間に 調郎して使佶できるという実際的な見地からと，高速 に礼ける軸の旋回に対して努定である事である。

[宮りI】行雄] 